\title{
Purification and polymerisation of microbial D-lactic acid from DDGS hydrolysates fermentation
}

Article

Accepted Version

Creative Commons: Attribution-Noncommercial-No Derivative Works 4.0

Zaini, N. A., Chatzifragkou, A., Tverezovskiy, V. and Charalampopoulos, D. (2019) Purification and polymerisation of microbial D-lactic acid from DDGS hydrolysates fermentation. Biochemical Engineering Journal, 150. 107265. ISSN 1369-703X doi:

https://doi.org/10.1016/j.bej.2019.107265 Available at https://centaur.reading.ac.uk/84142/

It is advisable to refer to the publisher's version if you intend to cite from the work. See Guidance on citing.

To link to this article DOI: http://dx.doi.org/10.1016/j.bej.2019.107265

Publisher: Elsevier

All outputs in CentAUR are protected by Intellectual Property Rights law, including copyright law. Copyright and IPR is retained by the creators or other copyright holders. Terms and conditions for use of this material are defined in the End User Agreement. 


\section{CentAUR}

Central Archive at the University of Reading

Reading's research outputs online 
$1 \quad$ Purification and polymerisation of microbial D-lactic acid from DDGS

\section{hydrolysates fermentation}

4 Nurul Aqilah Mohd Zaini ${ }^{\mathrm{a}, \mathrm{b}}$, Afroditi Chatzifragkou ${ }^{\mathrm{a}}$, Viacheslav Tverezovskiy ${ }^{\mathrm{c}}$, Dimitris

Charalampopoulos $\mathrm{a}^{\text {* }}$

6

$7 \quad{ }^{a}$ Department of Food and Nutritional Sciences, University of Reading, Whiteknights, PO Box 226, Reading RG6 6AP, United Kingdom

${ }^{\mathrm{b}}$ Centre for Biotechnology and Functional Food, Faculty of Science and Technology, Universiti Kebangsaan Malaysia, 43600 Bangi, Selangor, Malaysia

${ }^{\mathrm{c}}$ BioComposites Centre, Bangor University, Deiniol Road, Bangor, Gwynedd LL57 2UW,

"Correspondence concerning this manuscript to Professor Dimitris Charalampopoulos, Department of 


\section{Abstract}

A multi-step process was developed for microbial D-lactic acid purification, followed

23 by poly-D-lactic acid (PDLA) synthesis via azeotropic polycondensation process. Several

24 anion exchange resins were screened for their binding capacity using model lactic acid

25 solutions. Amberlite ${ }^{\circledR}$ IRA67 (weak base anion exchange resin) showed the highest lactic acid

26 adsorption, with maximum adsorption capacity, $q_{\max }$, of $136.11 \mathrm{mg}$ lactic acid / $\mathrm{g}$ of resin, and

27 was further selected to purify D-lactic acid from DDGS hydrolysates through a three-step

28 process; (1) treatment with $7 \%$ w/v activated carbon, (2) acidification of fermentation broth

29 (Amberlite ${ }^{\circledR}$ IRA120) and (3) adsorption of lactic acid by anion exchange (Amberlite ${ }^{\circledR}$ IRA67).

30 At the end of the purification process, $80.4 \%(\mathrm{w} / \mathrm{w})$ D-lactic acid was recovered with $91.8 \%$

31 (w/w) purity, indicating the effectiveness of the developed downstream process. Furthermore,

32 a clear yellowish solid polymer with a molecular weight of $3010 \mathrm{Da}$ was obtained, suitable for applications in biomedical and agricultural sectors.

35 Keywords: purification, activated carbon, ion exchange resin, poly-D-lactic acid, azeotropic polycondensation, DDGS 


\section{Introduction}

The world demand for lactic acid has increased significantly over the past few years, as the application of polylactic acid (PLA), offers distinctive advantages over petroleum-based polymers. PLA is a biodegradable plastic that can be used in biomedical and pharmaceutical industries as surgical suture, tissue engineering scaffolds or as drug delivery tool [1]. In the early stages of commercialisation, PLA was only produced for biomedical device applications due to its high cost [2]. Nowadays, the application of PLA has expanded to the electric and electronic industries for the production of casings and circuit boards, as well as in food industry for the production of food packaging and cutlery materials $[3,4]$. Currently, the main producers of PLA are NatureWorks ${ }^{\circledR}$ LLC under the trade name Ingeo ${ }^{\mathrm{TM}}$, Cereplast, Inc. (United States), Corbion Purac (Netherlands), Toray Industries (Japan) and Zhejiang Hisun Biomaterial Co., Ltd (China) [2]. Report by IHS Markit [5], predicted that PLA will be the leading application of lactic acid by 2020. PLA offers advantages over conventional petrochemical-derived plastics being biodegradable and compostable [2], and reduces the reliance on fossils fuel for the production of plastics [6]. Moreover, PLA production has a lower environmental impact compared to conventional petroleum derived polymers, as the carbon emissions and the energy consumption are reduced by 15 to $60 \%$ and 25 to $55 \%$, respectively [7]. The low toxicity of PLA, along with its positive environmental characteristics, has rendered it an ideal material for application in various fields, including the food, biomedical and agricultural sector [6].

The production of PLA from agricultural residues represents a promising route for production, as such biomass is available at low cost, is accessible throughout the year and does not compete with food crops. For example, corn stover [8] and rice bran [9] have been identified as potential fermentation substrates for D-lactic acid production. However, the fermentation broths derived from renewable sources contain a mixture of compounds, including a variety of 
sugars and proteins, polyphenols and organic acids, and thus require an effective downstream processing for the successful recovery of the targeted compound before being used as monomer for polymer synthesis [10].

Several downstream processing techniques such as ion exchange chromatography, precipitation, solvent extraction, distillation, nanofiltration, membrane extraction and electrodialysis have been investigated for the recovery and purification of lactic acid from fermentation broths [11-15]. Among these, adsorption by ion exchange offers a distinct advantage as it is a simple and relatively cheap process that offers product specificity, which leads to high purification yields $[14,16]$. In organic acid separation, anion exchange resins are widely used. However, no specific conclusions on the optimum conditions for lactic acid binding have been drawn so far for anion exchange resins. For example, some researchers reported that a solution $\mathrm{pH}$ above the $\mathrm{pKa}$ of lactic acid (pKa lactic acid, 3.86) give the highest binding of lactic acid to Amberlite ${ }^{\circledR}$ IRA67 [17], Amberlite ${ }^{\circledR}$ IRA96 [16] and Amberlite ${ }^{\circledR}$ IRA92 [18]. On the other hand, other studies have found that a $\mathrm{pH}$ below the $\mathrm{pKa}$ value give the highest adsorption of lactic acid and other carboxylic acids to Amberlite ${ }^{\circledR}$ IRA67 [19], Amberlite ${ }^{\circledR}$ IRA35 [20, 21] and Lewatit S3428 resins [22]. To promote lactic acid binding on an anionic resin below the pKa value, the fermentation broth was acidified by treatment with strong acid or by passing the broth through a strong acidic cation exchange resin, i.e. Duolite C-464, to convert lactate salt to lactic acid [21].

Ring opening polymerisation and direct polycondensation are the most common methods used to synthesise PLA from lactic acid. In ring opening polymerisation, PLA is polymerised through a cyclic lactide intermediate. Companies such as NatureWorks ${ }^{\circledR}$ LLC (United States) and Corbion N.V. (Netherlands), produce PLA through this route [4, 23, 24]. This protocol is of interest as it produces high molecular weight PLA. However, the procedure is complicated and time consuming because it involves several polymerisation steps and 
requires high purity of the lactide monomer prior to PLA synthesis [25]. On the other hand, direct polycondensation offers significant advantages as the polymerisation process is simpler and easier in this case. In direct polycondensation, only one step for polymer synthesis is involved, during which the lactic acid solution is heated at $130-140{ }^{\circ} \mathrm{C}$. Through this process, normally low molecular weight PLA $(<5000 \mathrm{Da})$ is produced with relatively weak mechanical properties; this is due to difficulties in removing the water from the reaction mixture as the polymerisation process progresses [26]. However, Ajioka, Enomoto, Suzuki and Yamaguchi [27] successfully produced high molecular weight PLA (> $300000 \mathrm{Da})$ using a single step synthesis using organic solvent with a catalyst (tin, Sn, powder) in azeotropic condition. Azeotropic polycondensation involved refluxing of the solvent under reduced pressure to remove the condensation water that was generated during polymer synthesis. This method had been patented and used by Mitsui Toatsu Chemicals (Japan) to synthesise PLA under the commercial name LACEA $[6,23]$.

The aim of the study was to develop a multi-step process for the purification of D-lactic 102 acid from a fermentation broth based on dried distiller's grains with solubles (DDGS) 103 hydrolysate [28]. Subsequently, the purified D-lactic acid was used as monomer for PDLA 104 synthesis by employing an azeotropic polycondensation approach. As the purification of D105 lactic acid from fermentation broth hydrolysates and its polymerisation process is rarely been

106 reported, this study provides novel information on D-lactic acid separation, employing a 107 multiple purification step followed by single step polymerisation process. 
$110 \quad 2.1 \quad$ Materials

Dried Distillers Grains with Solubles (DDGS) was supplied from a bioethanol plant

112 (Vivergo, Yorkshire, UK) and was alkaline pretreated as described by Zaini et al. [28]. Alkaline

113 treated DDGS consisted of $52.6 \mathrm{~g}$ glucose, $25.0 \mathrm{~g}$ xylose, $10.3 \mathrm{~g}$ arabinose, and $0.04 \mathrm{~g}$ protein

114 per $100 \mathrm{~g}$ of dried material. The resins (Amberlite ${ }^{\circledR}$ IRA67, Diaion ${ }^{\circledR}$ WA30, Amberlite ${ }^{\circledR}$

115 IRA400, Dowex ${ }^{\circledR}$ Marathon ${ }^{\mathrm{TM}}$ MSA and Amberlite ${ }^{\circledR}$ IRA120) and activated carbon used in

116 this study were purchased from Sigma-Aldrich (US).

117

$118 \quad 2.2 \quad$ D-lactic acid production

119 D-lactic acid was produced by L. coryniformis subsp. torquens (DSM 20004) using a

120 Simultaneous Saccharification and Fermentation (SSF) process of alkaline treated DDGS in a

1212 L stirred tank bioreactor (Biostat B, Sartorious, Germany) [28]. The process was initiated by

122 the simultaneous addition of Accellerase ${ }^{\circledR} 1500$ ( $1 \mathrm{ml}$ enzyme : $0.33 \mathrm{~g}$ cellulose $)$ and $L$.

123 coryniformis inoculum (starting OD of $\sim 0.05$ ) and was carried out for 30 hours (1.5 L

124 fermentation medium). The SSF process was carried out at $37^{\circ} \mathrm{C}$ with an initial agitation speed

125 of $250 \mathrm{rpm}$. The $\mathrm{pH}$ of fermentation medium was maintained at 5 with aseptic additions $5 \mathrm{M}$

$126 \mathrm{NaOH}$ and $\mathrm{HCl}$ through a peristaltic pump. The minimum dissolved oxygen (DO) level was

127 kept at $20 \%$ by controlling automatically the stirrer speed. The culture containing the enzyme

128 was inactivated by heat treatment at $95{ }^{\circ} \mathrm{C}$ for 10 minutes, followed by centrifugation at 17,105

$129 x \mathrm{~g}$ for 20 minutes $\left(4^{\circ} \mathrm{C}\right)$. Supernatants containing D-lactic acid solutions were collected and

130 kept at $-20{ }^{\circ} \mathrm{C}$ for purification. 
134 exchange resins (Amberlite ${ }^{\circledR}$ IRA400 and Dowex ${ }^{\circledR}$ Marathon ${ }^{\mathrm{TM}}$ MSA) were selected for this study. Before utilisation, the resins in free base form, were first converted to $\mathrm{Cl}^{-}$form as described by Moldes et al. [29]. Resins that were purchased in $\mathrm{Cl}^{-}$form were only washed with

137 distilled water [11, 30]. For the acidification of the fermentation broth, a cation exchange resin,

138 Amberlite ${ }^{\circledR}$ IRA120, a strongly acidic resin in $\mathrm{H}^{+}$form, was used. The resin was washed with distilled water three times to remove any contaminants. All resins were then oven dried at 50

${ }^{\circ} \mathrm{C}$ overnight and stored at room temperature in closed containers before use. The properties of

141 the ion exchange resins that were used in this study are presented in Table 1.

\subsubsection{Effect of $\mathrm{pH}$ on lactic acid binding} according to Bishai et al. [16] with slight modifications. $1 \mathrm{~g}$ of dried resin (Amberlite ${ }^{\circledR}$ IRA67,

151 Diaion ${ }^{\circledR}$ WA30, Amberlite ${ }^{\circledR}$ IRA400 or Dowex ${ }^{\circledR}$ Marathon ${ }^{\text {TM }}$ MSA) was mixed with 5 ml of

152 lactic acid $(50 \mathrm{~g} / \mathrm{l})$ at different initial $\mathrm{pH}$ conditions $(2,3,4,5,6,7$ and 8$)$ at $25^{\circ} \mathrm{C}$. The $\mathrm{pH}$ of

153 the solutions was adjusted with $5 \mathrm{M} \mathrm{NaOH}$. The mixtures were shaken at $200 \mathrm{rpm}$ for 8 hours. 
154 The liquid fractions from each mixture were collected by filtration and analysed for lactic acid concentration by HPLC.

\subsubsection{Effect of temperature on lactic acid binding}

In order to investigate the effect of temperature on lactic acid binding, $1 \mathrm{~g}$ of each dried resin (Amberlite ${ }^{\circledR}$ IRA67, Diaion ${ }^{\circledR}$ WA30, Amberlite ${ }^{\circledR}$ IRA400 or Dowex ${ }^{\circledR}$ Marathon ${ }^{\text {TM }}$ MSA) was mixed with $5 \mathrm{ml}$ lactic acid $(50 \mathrm{~g} / \mathrm{l})$, prepared at the optimum $\mathrm{pH}$ (obtained in Section shaken at 200 rpm for 8 hours. The liquid fractions from each mixture were collected by filtration and analysed for lactic acid concentration by HPLC. temperatures were calculated as follows, as described by Pradhan et al. [11]:

$$
\begin{gathered}
q=\frac{\left(C_{i}-C_{f}\right) * V}{R} \\
E=\frac{\left(C_{i}-C_{f}\right)}{C_{i}} * 100
\end{gathered}
$$

where, $q$ is the amount of lactic acid adsorbed to the resin $(\mathrm{mg} / \mathrm{g}), E$ is the efficiency of lactic acid binding (\%), $C_{i}$ is the initial concentration of lactic acid $(\mathrm{g} / \mathrm{l}), C_{f}$ is the concentration of lactic acid after being mixed with the resin (g/l), $V$ is the volume of lactic acid solution (l) and $R$ is the weight of the resin $(\mathrm{g})$.

\subsubsection{Adsorption capacity of lactic acid by resins} analysis in batch operation as described by Bernardo et al. [31] and John et al. [17], with slight modifications. $1 \mathrm{~g}$ of each resin was mixed with $5 \mathrm{ml}$ of lactic acid at various concentrations 
175 (4- $650 \mathrm{mg}$ lactic acid per $5 \mathrm{ml}$ ). The initial $\mathrm{pH}$ of the lactic acid solutions was set taking into 176 account their optimum binding $\mathrm{pH}$ (obtained in Section 2.4.1) for the respective resin. The 177 reaction took place at optimum temperature (obtained in Section 2.4.2) at $200 \mathrm{rpm}$ for 8 hours. 178 Liquid samples from each mixture were filtered and collected for further analysis. the following equations:

$$
\begin{aligned}
& \text { Langmuir model } \\
& \qquad \begin{array}{l}
q=\frac{q_{\max } * K * C}{K * C+1} \\
\text { Freundlich model } \\
\text { Langmuir - Freundlich model } \\
\qquad \frac{q}{q_{\max }}=\frac{K_{L F} * C^{\frac{1}{n}}}{1+K_{L F} * C^{n L F}}
\end{array}
\end{aligned}
$$

where, $q$ is the amount of lactic acid adsorbed to the resin $(\mathrm{mg} / \mathrm{g}), q_{\max }$ is the maximum amount of lactic acid adsorbed to the resin $(\mathrm{mg} / \mathrm{g}), K$ is the Langmuir adsorption constant, $K_{f}$ is the Freundlich adsorption constant, $K_{L F}$ is the affinity constant for adsorption, $C$ is the amount of lactic acid (mg), $n$ is the Freundlich adsorption constant and $n L F$ is the Langmuir-Freundlich coefficient. selected for further recovery experiments using $\mathrm{HCl}$ with different ionic strengths as eluent. 4 $191 \mathrm{~g}$ of Amberlite ${ }^{\circledR}$ IRA67 were packed into a $100 \mathrm{~mm}$ (length) column (Fisher Scientific, 192 Leicester, UK) and saturated with $20 \mathrm{ml}$ of $30 \mathrm{~g} / 1$ lactic acid solution. The resin was then washed with distilled water to remove any unbound lactic acid. Different concentrations of $\mathrm{HCl}$ 
194 were used as eluent $(0.05,0.1,0.5$ and $1.0 \mathrm{M})$, which were passed down the packed column by 195 gravity and fractions of effluents were collected ( $2 \mathrm{ml}$ per fraction) at regular time intervals.

196 All fractions were analysed for lactic acid concentration.

197

$198 \quad 2.5 \quad$ Purification of D-lactic acid from fermentation broth

$199 \quad 2.5 .1$ Colour removal by activated carbon

The effect of activated carbon on the removal of the colour from the fermentation broth was determined. Powdered activated carbon was mixed with $5 \mathrm{ml}$ of clarified fermentation broth at different loading concentrations $\left(0,1,5,7\right.$ and $10 \%$, w/v), for 1.5 hours at $150\left(25^{\circ} \mathrm{C}\right)$. The mixture was then separated by centrifugation at $17,105 \times \mathrm{g}$ for 10 minutes $\left(4^{\circ} \mathrm{C}\right)$. The pellet was washed twice with distilled water and the supernatants collected for sugar and lactic acid analysis.

\subsubsection{Acidification of fermentation broth by cation exchange resin}

After treatment with activated carbon, the fermentation broth was subjected to Amberlite ${ }^{\circledR}$ IRA $120, \mathrm{H}^{+}$resin aiming to convert sodium lactate into lactic acid [33]. $10 \mathrm{~g}$ of

210 dried resin were packed into a $30 \mathrm{~cm}$ length Econo-glass column (i.d. $1 \mathrm{~cm}$ ) which was first

211 filled with distilled water and the height of the resin was fixed with a flow adaptor (i.d. $1 \mathrm{~cm}$ )

212 (Biorad, California, US). Distilled water was allowed to pass through the column until the $\mathrm{pH}$ 213 of effluent was around 6.5. Then, a constant flow of $3 \mathrm{ml} / \mathrm{min}$ using a peristaltic pump was 214 applied. The fermentation broth containing sodium lactate with a $\mathrm{pH}$ around 5.5 was then 215 pumped into the column at the same flow rate. When the $\mathrm{pH}$ of the effluent started to increase, the resin was considered saturated. Effluent fractions (4 $\mathrm{ml}$ each) were collected for lactic acid 
217 and sugar analysis. Fractions containing D-lactic acid were pooled for subsequent purification.

218 The resin was washed with distilled water to remove the remaining solution in interstitial 219 spaces, regenerated with $1 \mathrm{M} \mathrm{HCl}$ and thoroughly rinsed with distilled water, before a new 220 cycle [16].

2.5.3 Adsorption by anion exchange resin

Pooled supernatant fractions containing D-lactic acid were passed through an anion exchange resin, (Amberlite ${ }^{\circledR}$ IRA67) in fixed-bed column operation. $25 \mathrm{~g}$ of dried resin were packed into a $30 \mathrm{~cm}$ length Econo-glass column (i.d. $2.5 \mathrm{~cm}$ ) which was first filled with distilled water and the upper side of resin was fixed with a flow adaptor (i.d. $2.5 \mathrm{~cm}$ ). The system was washed with distilled water until the $\mathrm{pH}$ of the effluent was around 6.5. Then, the acidified broth obtained from Amberlite ${ }^{\circledR}$ IRA 120, $\mathrm{H}^{+}$resin was pumped into the column at $3 \mathrm{ml} / \mathrm{min}$. $\mathrm{D}=$ lactic acid was recovered with $0.5 \mathrm{M} \mathrm{HCl}$. Fractions of effluents at each stage were collected (4 ml each) for lactic acid and sugar analysis.

\subsection{Azeotropic polycondensation process of PDLA}

Polycondensation of PDLA was conducted as described by Ajioka et al. [27] with minor modifications. $2 \mathrm{~g}$ of D-lactic acid were mixed with $40 \mathrm{ml}$ toluene in $100 \mathrm{ml}$ reaction flask, equipped with a Dean-stark apparatus and a magnetic stirrer. In the first step of the polycondensation process, the mixture was azeotropically dehydrated at $110{ }^{\circ} \mathrm{C}$ for 3 hours to remove the free water. After removing the condensed water that was trapped in the Dean-stark apparatus, the tube was packed with molecular sieve (4 $\AA$ ) and calcium chloride in layers to remove small amounts of water dissolved in the organic solvent that was produced during PLA synthesis. $0.2 \mathrm{~g}$ tin (1l)-2-ethylhexanoate (stannous octoate) was added to the reaction mixture 
241 and then returned to reflux at $140{ }^{\circ} \mathrm{C}$ for another 80 hours. The polymer produced was then

242 recovered by filtration and vacuum dried using Bünchner funnel apparatus, followed by freeze 243 drying (VisTis Sentry 2.0, Warminster, PA). described by Lie [34] with some modifications. $0.5 \mathrm{ml}$ of diluted sample was mixed with 0.25 $\mathrm{ml}$ of colour reagent $\left(49.71 \mathrm{~g}\right.$ of $\mathrm{Na}_{2} \mathrm{HPO}_{4} \cdot 2 \mathrm{H}_{2} \mathrm{O}, 5 \mathrm{~g}$ of ninhydrin, $3 \mathrm{~g}$ of fructose and $\sim 40 \mathrm{~g}$ of $\mathrm{KH}_{2} \mathrm{PO}_{4}$ dissolved in 11 of distilled water; $\mathrm{pH} 6.6-6.8$ ) in $2 \mathrm{ml}$ Eppendorf tube. The mixture was heated at $100{ }^{\circ} \mathrm{C}$ in a thermal block (Grant, Cambridge) for exactly 16 minutes and immediately cooled in an ice bath. $1.5 \mathrm{ml}$ of dilution reagent $\left(2 \mathrm{~g}\right.$ potassium iodate, $\mathrm{KIO}_{3}$, in $616 \mathrm{ml}$ distilled water and $384 \mathrm{ml} \mathrm{96 \%} \mathrm{ethanol)} \mathrm{was} \mathrm{added} \mathrm{and} \mathrm{the} \mathrm{free} \mathrm{amino} \mathrm{nitrogen} \mathrm{content}$ was measured at $570 \mathrm{~nm}$. A calibration curve was constructed using glycine at different concentrations $(0.25-2 \mathrm{mg} / \mathrm{l})$ as standard.

Sugar and lactic acid concentrations were analysed by high performance liquid chromatography (HPLC) in an Agilent Infinity 1260 system (Agilent Technologies, USA) equipped with an Aminex HPX-87H column (Bio-rad, Hercules, CA) at a $0.6 \mathrm{ml} / \mathrm{min}$ flow rate with $5 \mathrm{mM} \mathrm{H}_{2} \mathrm{SO}_{4}$ as mobile phase. The temperature of the column was set at $65{ }^{\circ} \mathrm{C}$ and sugars and lactic acid were detected using a refractive index detector. The D-lactic acid recovery and 260 purity were calculated using the following equations [16]:

$$
\begin{gathered}
\text { Recovery }(\%)=\frac{m g \text { LA in each purification stage }}{m g \text { LA in fermentation broth }} * 100 \\
\text { Purity }(\%)=\frac{\text { HPLC peak area of LA in each purification stage }}{\text { Total HPLC peak areas in each purification stage }} * 100
\end{gathered}
$$



permeation chromatography (GPC), using an Agilent 1100 Series chromatography system that was equipped with a refractive index RID 1200 detector $\left(35^{\circ} \mathrm{C}\right)$. The flow rate was set at 1.0 $\mathrm{ml} / \mathrm{min}$ and the molecular size was determined using a PL gel $5 \mu \mathrm{M}$ mixed-D column $(300 \mathrm{x}$ $7.5 \mathrm{~mm})$ and a PL gel $5 \mu \mathrm{M}$ guard column $(50 \times 7.5 \mathrm{~mm})$. Chloroform was used as the eluent. The PDLA obtained was first dissolved in chloroform prior to analysis. The sample was analysed at room temperature using $20 \mu$ l injection volume. A calibration curve was generated using polystyrene standards with molecular weights ranging from 580 to 483,400 Da.

\section{Results and Discussion}

\subsection{Selection of anion exchange resin}

When considering ion exchange chromatography, the efficiency of the product adsorption by the resin determines the success of the purification process. Therefore, factors such as $\mathrm{pH}$, temperature and lactic acid concentration were initially investigated in this study in order to select the most appropriate anion exchange resin. The effect of the ionic strength of the eluent ( $\mathrm{HCl}$ solution) on product recovery was also investigated. Before use, the resins that existed in free base were converted to $\mathrm{Cl}^{-}$form. The $\mathrm{Cl}^{-}$form was selected as previous studies have shown that in this form the resins exhibit the highest adsorption capacity for lactic acid $[17,31]$. Moreover, the simultaneous lactic acid recovery and resin regeneration for subsequent adsorption cycles by $\mathrm{HCl}$, reduces the number of steps involved in the purification process

281 [29]. Four different resins, categorised into weak base anion exchange (Amberlite ${ }^{\circledR}$ IRA67 and 282 Diaion $^{\circledR}$ WA30) and strong base anion exchange (Amberlite ${ }^{\circledR}$ IRA400 and Dowex ${ }^{\circledR}$ 
283 Marathon ${ }^{\mathrm{TM}} \mathrm{MSA}$ ) were tested against different initial $\mathrm{pH}$ values, ranging from 2 to 8 , as shown in Figure 6a.

Among the tested resins, the weak base anion exchange resins showed capability for lactic acid binding at low $\mathrm{pH}$, with the highest adsorption being $65 \%$ with Amberlite ${ }^{\circledR}$ IRA67 at $\mathrm{pH} 3$, which corresponded to a maximum binding capacity $\left(q_{\max }\right)$ of $155 \mathrm{mg}$ lactic acid/g of resin. For strong base anion exchange resins, less than $22 \%$ of lactic acid was adsorbed by both Amberlite ${ }^{\circledR}$ IRA400 and Dowex ${ }^{\circledR}$ Marathon ${ }^{\mathrm{TM}}$ MSA, with the highest binding at pH 6 and pH 4, respectively, suggesting that the $\mathrm{pH}$ did not influence the adsorption of lactic acid to the strong base anion exchange resins. On the other hand, the adsorption of weak base anion exchange resins was strongly influenced by the $\mathrm{pH}$ of the feed solution. In the case of Amberlite ${ }^{\circledR}$ IRA67 and Diaion ${ }^{\circledR}$ WA30, the best $\mathrm{pH}$ for lactic acid adsorption was below its pKa (3.86), where lactic acid exists in its undissociated form [21, 22, 35]. This can be associated with the charge of the tertiary amine (the functional group in both resins) which is cross-linked to the polymeric matrix (acrylic or styrene) in Amberlite ${ }^{\circledR}$ IRA67 and Diaion ${ }^{\circledR}$ WA30. It is assumed that the lone pair electron of the nitrogen atom in the tertiary amine is likely to hydrogen bond to lactic acid through the chloride ion $[20,36]$. This mechanism is also supported by works from Yousuf et al. [35], Kislik [13] and Kulprathipanja and Oroskar [20], who reported that possible interactions between amine-based extractants and carboxylic acids are through hydrogen bonding, acid-base interaction, hydrophobic interaction, ion-ion pair formation or solvation.

Subsequently, the effect of temperature $\left(25\right.$ to $\left.60{ }^{\circ} \mathrm{C}\right)$ on lactic acid adsorption was investigated at $\mathrm{pH}$ values that were previously shown to give the highest lactic acid binding for each resin (Figure 6b). No differences were observed between the different temperatures, for each resin. As shown previously, the highest lactic acid adsorption ( $73 \%)$ was exhibited by Amberlite $^{\circledR}$ IRA67. According to Niazi and Brown [37], the effect of temperature on ion 
exchange resins is mainly attributed to pKa changes of the targeted compound as a result of the temperature change. In the case of lactic acid, as the temperature increased from 25 to 30,40 and $50^{\circ} \mathrm{C}$, the pKa value also increased to $3.896,3.942$ and 4.028 , respectively [38]. Since

311 lactic acid adsorption to weak base anion exchange resins occurs below its pKa value, the

312 increase in temperature from 25 to $60{ }^{\circ} \mathrm{C}$ did not have any significant effect.

\subsubsection{Adsorption isotherms} shown in

317 Figure 7a and 2b, respectively. Different kinetic models (Langmuir, Freundlich and Langmuir 318 - Freundlich) were then used to fit the data, and the model parameters are presented in Table 2.

The Langmuir and Langmuir - Freundlich models fitted better the data for both resins $\left(\mathrm{R}^{2}>0.9\right)$, compared to the Freundlich model $\left(\mathrm{R}^{2}=0.80\right)$. The Langmuir - Freundlich model showed better fit than the Langmuir model for both the Amberlite ${ }^{\circledR}$ IRA67 $\left(R^{2}=0.94\right)$ and the Diaion ${ }^{\circledR}$ WA30 resin $\left(\mathrm{R}^{2}=0.965\right)$. In the Langmuir model, it is assumed that the adsorption of a given adsorbate occurs as a monolayer sorption onto the surface of a resin containing a finite number of identical binding sites. The adsorbent has uniform binding sites and the adsorbate will only bind to the binding site $[32,39]$. In the Freundlich model, it is assumed that the binding of the adsorbate molecules onto the adsorbent is at infinite capacity. The adsorption is not uniform and can occur in a multilayer, with the binding site that has stronger bond energy being occupied first [39]. In the present study, the adsorption capacity of the resin was specific due to the strong interactions between lactic acid and the functional groups present in the $\mathrm{Cl}^{-}$ form of the resin. As a result, the Freundlich model did not fit as well as the other models the 
332 kinetic data. According to Sala et al. [32], the Langmuir-Freundlich model is the simple

333 generalisation of both isotherms, modelling the adsorption cooperativity of the two different

334 binding mechanisms. This level of cooperativity can be determined from the $n L F$ value, where,

335 when $n L F>1$, a positive cooperativity is indicated. When $0<n L F<1$, a negative cooperativity

336 in binding process is indicated, whereas when $n F L$ value $=1$, it is assumed that the adsorption

337 is purely independent, and no interaction takes place between absorbents. In this study, the $n F L$

338 values for both resins were > 1, with 1.96 for Amberlite ${ }^{\circledR}$ IRA67and 1.83 for Diaion ${ }^{\circledR}$ WA30,

339 indicating a positive cooperativity of the two binding mechanisms.

340 The maximum binding capacity of a resin $\left(q_{\max }\right)$ can also be predicted from the

341 Langmuir and Langmuir-Freundlich models, however it cannot be obtained from the

342 Freundlich model as this model assumes that lactic acid binding to the resin is unlimited. The

343 highest $q_{\max }$ values for Amberlite ${ }^{\circledR}$ IRA67 were 162.09 and $136.11 \mathrm{mg} / \mathrm{g}$ resin based on the

344 Langmuir and Langmuir-Freundlich models, respectively. This value, however, was lower

345 than the $q_{\max }$ value reported by Garrett et al. [40], i.e. $203 \mathrm{mg} / \mathrm{g}$ of resin, as predicted by the

346 Langmuir model.

$348 \quad 3.1 .2$ Effect of $\mathrm{HCl}$ strength on the recovery of lactic acid

The strength of the eluent on the recovery of lactic acid plays a key role for ensuring that all of the lactic acid that is bound to the resin is detached. In this study, $\mathrm{HCl}$ was used as an eluent to recover lactic acid from Amberlite ${ }^{\circledR}$ IRA67, which was deemed from the previous work to be the most suitable resin. Figure 8 depicts the elution profiles of lactic acid at different $\mathrm{HCl}$ concentrations. At $0.05 \mathrm{M}$ and $0.1 \mathrm{M} \mathrm{HCl}$, only 5.1 and $22.1 \%$ lactic acid was recovered

354 from Amberlite ${ }^{\circledR}$ IRA67, respectively. However, at 0.5 and $1.0 \mathrm{M}, \sim 96 \%$ and $100 \%$ recovery of lactic acid was achieved, respectively, indicating that the strength of the eluent plays critical 
role for the detachment of lactic acid from the resin. Based on these results, $0.5 \mathrm{M} \mathrm{HCl}$ was selected to recover lactic acid in subsequent experiments.

3.2 Separation and purification of D-lactic acid from fermentation broth

3.2.1 Colour removal by activated carbon

After determining the conditions leading to maximum lactic acid adsorption and recovery using the Amberlite ${ }^{\circledR}$ IRA67 resin, the aim was to purify lactic acid from fermentation broths of L. coryniformis subsp. torquens, where DDGS hydrolysate was used as the fermentation medium. Fermentation broths usually contain besides the component of interest, residual sugars and proteins, as well as by-products of the fermentation process. In this particular case, fermented DDGS hydrolysate contained residual sugars (xylotriose, xylobiose, xylose, arabinose), organic nitrogen in the form of proteins, peptides or amino acids, polyphenols and acetic acid, all of which can contributed into the dark brown colour of the fermentation broth [41]. It is likely that a significant proportion of the dark brown colour of the medium is due to the dark colour of DDGS generated during the drum drying step in the DDGS production process. Therefore, prior to ion exchange purification, the fermented DDGS hydrolysate was initially subjected to activated carbon treatment. Figure 9 shows the effect of various activated carbon concentrations on the colour of the fermentation broth. A positive correlation can be observed as the activated carbon concentrations increased up to $5 \%(\mathrm{w} / \mathrm{v})$ and the colour of the fermentation broths became notably lighter. For higher activated carbon concentrations ( 7 and 10\%, w/v) no significant changes in colour were observed.

The effect of activated carbon concentration on the recovery of D-lactic acid, protein, oligosaccharides and monosaccharides is shown in Table 3. The recovery of D-lactic acid gradually decreased as the concentration of activated carbon increased. More specifically at 1 , 

fermentation broth, respectively. A relatively small reduction in monosaccharides and proteins concentrations was overall noted $(<30 \%$ removal $)$ when the fermentation broth was treated with activated carbon, even as high as $10 \%(w / v)$. Stone and Kozlov [42] reported that activated carbon can only adsorb low molecular weight proteins, in which is in line with protein removal data obtained in this study. On the other hand, oligosaccharides (xylotriose and xylobiose) were completely removed at 7\% (w/v) activated carbon. According to Boon et al. [43], activated carbon has higher affinity for trisaccharides and disaccharides compared to monosaccharides with a capacity of $133 \mathrm{mg} / \mathrm{g}$ and $117 \mathrm{mg} / \mathrm{g}$ of activated carbon, respectively. Based on the above, $7 \%(\mathrm{w} / \mathrm{v})$ activated carbon was selected as the best concentration to treat the fermentation broth to ensure a satisfactory recovery of lactic acid and at the same time the removal of oligosaccharides and partially of proteins and monosaccharides.

\subsubsection{Acidification of fermentation broth by cation exchange chromatography}

In lactic acid fermentations, the $\mathrm{pH}$ of the culture is normally controlled to prevent microbial growth inhibition and ensure an adequate growth of lactic acid bacteria [44]. $\mathrm{NaOH}$ is often selected as the neutralising agent because of its low cost and the fact that no gypsum is generated as a by-product which is the case when $\mathrm{Ca}(\mathrm{OH})_{2}$ is used [45]. As a result, sodium lactate is formed in the fermentation broth. In order to recover lactic acid by anion exchange chromatography, the $\mathrm{pH}$ of the broth needs to be reduced to below $\mathrm{pH} 3$ in order for lactic acid to be in its undissociated form rather than in the form of salt. To achieve this and taking into account that the $\mathrm{pH}$ of the fermentation broth used in this study was $\sim 5.5$, the fermentation broth was passed through the Amberlite ${ }^{\circledR}$ IRA120 $\left(\mathrm{H}^{+}\right)$cation exchange resin, in order to exchange the sodium ions and release lactate ions into the solution. Figure 10a depicts the compositional profile of the solution during passing through the resin. 
In cation exchange chromatography, no eluent is needed as lactic acid does not bind to

406 Amberlite IRA $^{\circledR} 120\left(\mathrm{H}^{+}\right)$. Amberlite IRA ${ }^{\circledR} 120$ is a strong acidic cation exchange resin that

407 contains sulfonic acid functional groups. It is assumed that the hydrogen ions $\left(\mathrm{H}^{+}\right)$that are 408 attached to the resin's functional group will bind to sodium lactate and convert it to lactic acid 409 in the solution. At the same time, the cation of the lactate salt $\left(\mathrm{Na}^{+}\right)$will be transferred to the 410 cation exchange resin and transformed through the reaction: $\mathrm{P}-\mathrm{H}^{+}+\mathrm{Na}^{+} \mathrm{La}^{-} \rightarrow \mathrm{P}-\mathrm{Na}^{+}+\mathrm{H}^{+} \mathrm{La}^{-}$, 411 where $\mathrm{P}$ is the polymer matrix [46]. In the first $12 \mathrm{ml}$ of the fractions collected, no organic 412 acids and sugars were detected and the $\mathrm{pH}$ of the collected fraction was around 6.5, indicating 413 that the fraction contained only water (already present in the column). The $\mathrm{pH}$ of the solution 414 then dropped sharply and when it reached $\sim 2.3$, the presence of D-lactic acid and other 415 compounds such as acetic acid, xylose and arabinose were detected. The $\mathrm{pH}$ of eluate in the 416 collected fraction dropped further with time, to $\sim 1.5$, indicating that sodium lactate was 417 successfully converted to undissociated lactic acid. Fractions that had pH below 3 were then pooled together yielding a fraction with a $\mathrm{pH}$ of 1.67.

3.2.3 Recovery of D-lactic acid by anion exchange chromatography resin has significant commercial potential as it is a robust resin where the amines present in the functional group do not easily detach from the polymer matrix, it is easy to regenerate, and provides higher recovery of lactic acid compared to other resins. The results from this study (Figure 10b) show that during the binding stage, no lactic acid was present in the collected fraction, while other compounds such as xylose and arabinose were detected. The $\mathrm{pH}$ of the effluent collected during the binding stage was around 5.5 to 6.0 , indicating that the organic acids present in the fermentation broth (lactic acid and acetic acid) were adsorbed to the resin. 
430 After washing the column with water, lactic acid was desorbed with $0.5 \mathrm{M} \mathrm{HCl}$. The first acid

431 to be eluted was acetic acid, followed by lactic acid. Fractions that contained only lactic acid were pooled together.

Table 4 presents the recovery and purity of D-lactic acid, as well as the percentage of

434 total sugars and protein removal after each stage of the purification process. After the 435 fermentation broth was treated with $7 \%(w / v)$ activated carbon, a $\sim 96 \%$ recovery of D-lactic 436 acid recovery was observed and a $9.6 \%$ increase in D-lactic acid purity, the latter due to the 437 complete removal of oligosaccharides and of $55 \%$ of the proteins that were initially present in 438 the fermentation broth. During the cation exchange stage, a $\sim 93 \%$ recovery of D-lactic acid 439 compared to the D-lactic acid concentration in the fermentation broth was observed, and 440 although only $1 \%$ increase in D-lactic acid purity was detected, 21\% of total sugar and 44\% 441 of proteins were successfully removed at this stage. Cation exchange did not increase the D442 lactic acid purity as its main objective was to acidify the fermentation broth. During the anion 443 exchange step a $\sim 80.4 \%$ recovery of D-lactic acid was observed, while $74 \%$ of the sugars were 444 removed, leading to a cumulative sugar removal of $100 \%$. As a consequence, the purity of D445 lactic acid in the eluent was significantly increased during this step, reaching $91.8 \%$, with the 446 remaining components consisting most likely of small amounts of organic molecules, e.g. 447 proteins, acetic acid and other microbial metabolites. Optical purity values for D-lactic above $44892 \%$ acid are considered appropriate for the synthesis of PLA [44] and demonstrate that the 449 proposed multi-step downstream process has significant potential for scaling up and 450 commercialisation. 
The azeotropic dehydration polycondensation method was employed using toluene as solvent and tin (11)-2-ethylhexanoate (stannous octoate) as catalyst during polymerisation of Dlactic acid obtained from microbial fermentation of DDGS. Tin compounds and protonic acid have been found to be the best catalysts for the direct polycondensation of high molecular weight PLA [27]. However, stannous octoate is preferable as it is approved by U. S. Food and Drug Administration (FDA) in the list of Indirect Additives used in Food Contact Substances under the Code of Federal Regulation, Title 21 (Food and Drugs). In addition to that, the removal of water is crucial in the direct polycondensation process, as its presence could initiate transesterification reactions or chain terminating reactions of the PLA produced [26, 47]. During azeotropic polycondensation, the water that was present in the feedstock (D-lactic acid) or generated during the polymerisation process was continuously distilled off from the reaction mixture through the Dean-stark trapped apparatus.

After $80 \mathrm{~h}$ of polymerisation, a solid yellowish crystal PDLA was produced with an average molecular weight of $3010 \mathrm{Da}$ with a PDI of 4.1, categorised as low molecular weight PLA. In contrast, Kim and Woo [48] produced ten times higher molecular weight of PLLA (33000 Da) after $72 \mathrm{~h}$ reaction when the same polycondensation method was used. A similar finding was reported by Marques et al. [49], where 80,000 Da molecular weight of PLLA was produced after $70 \mathrm{~h}$ of polymer synthesis. The differences in the molecular weight produced in both cases might be due to the differences in the type of catalyst (tin (1l) chloride dihydrate) and solvent ( $m$-xylene with higher than toluene by $29^{\circ} \mathrm{C}$ boiling point) used during the polymerisation process in those cases. Moreover, other factors such as the purity of D-lactic acid, minute amounts of carboxylic acids like acetic acid, the presence of small amounts water during the polymerisation process and the reaction temperature might also have contributed to the generation of low molecular weight PDLA [12]. Table 5Error! Reference source not 
477 found. compares the molecular weight of PLA produced from this and other studies, where

478

480

481

482

483

484

485

486

487

488

489

490

491

492

493

494

495

496

497

498

499

500

501 various synthesis methods, monomers (D- or L- lactic acid) and catalysts were employed.

This is the first work demonstrating the synthesis of D-lactic acid polymer (PDLA) employing either a direct method or a one-step polymerisation (azeotropic polycondensation) process. Pivsa-Art et al. [50] synthesised PDLA via a two-step polycondensation process, which included a melt polymerisation step followed by solid state polymerisation, and produced PLA with a molecular weight of 33300 Da. A number of interesting applications for low molecular weight PLA have been proposed in various fields, especially in the biomedical [47] and agricultural fields [51]. In the biomedical field, low molecular weight PLA is used as particles for parental controlled drug release in the human body in the form of microspheres, microcapsules, pellets or tablets. Using this approach, drugs are fabricated in a polymeric device (PLA) and the release of the drug is regulated by either diffusion through the polymer barrier or erosion of the polymer matrix [52]. PLA is preferable compared to other polymers such as polyethylene and silicon rubber, as it does not require surgical retrieval, due to its natural degradation in the body. PLA is degraded by simple non-enzymatic hydrolysis (after exposure to moisture) to its monomer (lactic acid), which can be metabolised by the human body [47]. Drug delivery using low molecular weight PLA offers advantages over high molecular weight PLA as it has a weak retarding effect. Thus, the risk of material accumulation in tissues is reduced as PLA is relatively fast degraded to lactic acid [53].

The same mode of application (controlled release) is also being used in the agricultural field, specifically the agrochemical sector, where PLA can serve as carrier for herbicides and pesticides that are released into the soil. The advantages of using low molecular weight PLA have been demonstrated by Zhao and Wilkins [51], where delayed release of pesticides was observed in the early stages of application, which makes it desirable for sensitive targets such as seed treatment. In their study, bromacil (pesticide) was incorporated into PLA in the form 
502 of granules and films, and the delayed release of bromacil was achieved via degradation and erosion of PLA. Since the degraded monomer (lactic acid) is safe and widely distributed in nature, the environmental problems of polymer disposal can be avoided through this approach $505[6,51]$.

In addition, Quynh et al. [54] successfully produced PLA with high thermostability when commercial PLLA polymer (10400 Da) was crosslinked with low molecular weight

508 PDLA (9830 Da). The stereo complex formation of PLLA and PDLA was achieved via the melt polycondensation process and increased the melting temperature of PLA from $175.6{ }^{\circ} \mathrm{C}$ to $218.1^{\circ} \mathrm{C}$. This finding has widespread the application of PLA in other areas such as in the

511 production of computer casings, automotive components and heat resistant food packaging [2].

\section{Conclusions}

Low molecular weight PDLA (3010 Da) was produced via single step azeotropic polycondensation process from purified D-lactic acid originated from DDGS. The developed downstream process reduced effectively the dark colour of fermentation broth, removed oligosaccharides and converted sodium lactate to undissociated lactic acid. At the end of the purification process, approximately $80.4 \%$ D-lactic acid was recovered with $91.8 \%$ purity. This study demonstrated that agricultural residues, such as DDGS, hold potential as starting materials for biopolymer production.

\section{Acknowledgements}

524 the Universiti Kebangsaan Malaysia, Bangi (UKM), for providing a doctoral sponsorship and 525 financial support to carry out this research. 


\section{References}

528

529

530

531

532

533

534

535

536

537

538

539

540

541

542

543

544

545

546

547

[1] M. Hans, H. Keul, M. Moeller, Ring-Opening Polymerization of DD-Lactide Catalyzed by Novozyme 435, Macromol. Biosci. 9 (2009) 239-247.

[2] L.T. Sin, A.R. Rahmat, W.A.W.A. Rahman, 1 - Overview of Poly(lactic Acid), Polylactic Acid, William Andrew Publishing, Oxford, 2013, pp. 1-70.

[3] C. Ingrao, C. Tricase, A. Cholewa-Wójcik, A. Kawecka, R. Rana, V. Siracusa, Polylactic acid trays for fresh-food packaging: A Carbon Footprint assessment, Sci. Total Environ. 537 (2015) 385-398.

[4] NatureWorks LLC, Ingeo in use, NatureWorks LLC, 2017.

[5] IHS Markit, Lactic Acid, Its Salts and Esters, 2015.

[6] M. Jamshidian, E.A. Tehrany, M. Imran, M. Jacquot, S. Desobry, Poly-lactic acid: Production, applications, nanocomposites, and release studies, Compr. Rev. Food Sci. Food Saf. 9 (2010) 552-571.

[7] I.S. Tawakkal, M.J. Cran, J. Miltz, S.W. Bigger, A Review of Poly (Lactic Acid)-Based Materials for Antimicrobial Packaging, J. Food Sci. 79 (2014).

[8] Z. Bai, Z. Gao, B. He, B. Wu, Effect of lignocellulose-derived inhibitors on the growth and d-lactic acid production of Sporolactobacillus inulinus YBS1-5, Bioprocess. Biosyst. Eng. 38 (2015) 1993-2001.

[9] T. Tanaka, M. Hoshina, S. Tanabe, K. Sakai, S. Ohtsubo, M. Taniguchi, Production of Dlactic acid from defatted rice bran by simultaneous saccharification and fermentation, Bioresour. Technol. 97 (2006) 211-217. 
551 Esposito, Adsorption Behaviour of Lactic Acid on Granular Activated Carbon and Anionic

552 Resins: Thermodynamics, Isotherms and Kinetic Studies, Energies. 10 (2017) 665.

553 [12] S. Inkinen, M. Hakkarainen, A.-C. Albertsson, A. Södergård, From Lactic Acid to 554 Poly(lactic acid) (PLA): Characterization and Analysis of PLA and Its Precursors, 555 Biomacromolecules. 12 (2011) 523-532.

[13] V.S. Kislik, Chapter 2 - Principles of Solvent Extraction of Organic and Mineral Acids, Solvent Extraction, Elsevier, Amsterdam, 2012, pp. 69-111.

Recovery Processes of Organic Acids from Fermentation Broths in the Biomass-Based 560 Industry, J. Microbiol. Biotechnol. 26 (2016) 1-8.

[15] A. Komesu, M.R.W. Maciel, R. Maciel Filho, Separation and Purification Technologies for Lactic Acid-A Brief Review, BioResources 12 (2017) 6885-6901. acid from a fermentation broth of novel substrate Zizyphus oenophlia, 3 Biotech 5 (2015) 455463.

[17] R.P. John, K.M. Nampoothiri, A. Pandey, L (+)-Lactic acid recovery from cassava bagasse based fermented medium using anion exchange resins, Braz. Arch. Biol. Technol. 51 (2008) $1241-1248$ of L (+)-lactic acid from fermentation broth with paper sludge as a cellulosic feedstock using weak anion exchanger Amberlite IRA-92, Biochem. Eng. J. 18 (2004) 89-96. 
572 [19] N. Murali, K. Srinivas, B.K. Ahring, Biochemical Production and Separation of

573 Carboxylic Acids for Biorefinery Applications, Fermentation. 3 (2017) 22.

574 [20] S. Kulprathipanja, A.R. Oroskar, Separation of lactic acid from fermentation broth with 575 an anionic polymeric absorbent, Google Patents, 1991.

576 [21] R.L. Evangelista, Z.L. Nikolov, Recovery and Purification of Lactic Acid from

577 Fermentation Broth by Adsorption, in: C.E. Wyman, B.H. Davison (Eds.) Seventeenth 578 Symposium on Biotechnology for Fuels and Chemicals: Presented as Volumes 57 and 58 of 579 Applied Biochemistry and Biotechnology, Humana Press, Totowa, NJ, 1996, pp. 471-480.

580 [22] M.I. González, S. Álvarez, F.A. Riera, R. Álvarez, Purification of lactic acid from 581 fermentation broths by ion-exchange resins, Ind. Eng. Chem. Res. 45 (2006) 3243-3247.

582 [23] E.T.H. Vink, K.R. Rábago, D.A. Glassner, P.R. Gruber, Applications of life cycle 583 assessment to NatureWorks ${ }^{\mathrm{TM}}$ polylactide (PLA) production, Polym. Degrad. Stab. 80 (2003) $584 \quad 403-419$.

585 [24] Corbion N.V., PLA polymers, Corbion N.V., 2017.

586 [25] L. Xiao, B. Wang, G. Yang, M. Gauthier, Poly (lactic acid)-based biomaterials: synthesis, 587 modification and applications, Biomedical Science, Engineering and Technology, $588 \quad$ InTech2012.

589 [26] A. Södergård, S. Inkinen, Production, chemistry and properties of polylactides, 590 Biopolymers-New Materials for Sustainable Films and Coatings (2011) 43-63.

591 [27] M. Ajioka, K. Enomoto, K. Suzuki, A. Yamaguchi, The basic properties of poly(lactic 592 acid) produced by the direct condensation polymerization of lactic acid, J. Environ. Polym.

593 Degrad. 3 (1995) 225-234. 
594 [28] N.A.M. Zaini, A. Chatzifragkou, D. Charalampopoulos, Microbial production of D-lactic 595 acid from Dried Distillers Grains with Solubles (DDGS), Eng. Life Sci. 19 (2019) 21 - 30. and fermentation media using anion exchange resins, Bioprocess. Biosyst. Eng. 25 (2003) 357363.

599 [30] The Dow Chemical Company, DOW Ion Exchange Resins - Pre-use Preparation - Resin 600 for industrial use, 2017.

601 [31] M.P. Bernardo, L.F. Coelho, D.C. Sass, J. Contiero, 1-(+)-Lactic acid production by 602 Lactobacillus rhamnosus B103 from dairy industry waste, Braz. J. Microbiol. 47 (2016) 640603646.

604 [32] L. Sala, F.S. Figueira, G.P. Cerveira, C.C. Moraes, S.J. Kalil, Kinetics and adsorption 605 isotherm of C-phycocyanin from Spirulina platensis on ion-exchange resins, Braz. J. Chem. 606 Eng. 31 (2014) 1013-1022.

607 [33] S.M. Beitel, D.C. Sass, L.F. Coelho, J. Contiero, High D (-) lactic acid levels production 608 by Sporolactobacillus nakayamae and an efficient purification, Ann. Microbiol. 66 (2016) $609 \quad 1367-1376$.

610 [34] S. Lie, The EBC-Ninhydrin method for determination of free alpha amino nitrogen, J. I. 611 Brewing 79 (1973) 37-41.

612 [35] A. Yousuf, F. Bonk, J.-R. Bastidas-Oyanedel, J.E. Schmidt, Recovery of carboxylic acids 613 produced during dark fermentation of food waste by adsorption on Amberlite IRA-67 and 614 activated carbon, Bioresour. Technol. 217 (2016) 137-140.

615 [36] N. Syzova, A.M. Eyal, A. Vitner, B. Hazan, Extraction of Carboxylic Acids by ABC 616 Extractants: Effects of Temperature, the Polarity of the Diluent, and the Ratio Between 617 Extractant Components, Solvent Extr. Ion Exc. 22 (2004) 69-88. 
618 [37] S.K. Niazi, J.L. Brown, Fundamentals of Modern Bioprocessing, CRC Press, Boca Raton, 619 FL, 2016.

620 [38] Saeeduddin, A. Khanzada, Dissociation constant studies of lactic acid at different 621 temperatures and in mixed organic-water solvent systems, J. Chem. Soc. Pakistan 26 (2004) $622 \quad 23-27$.

623 [39] K.Y. Foo, B.H. Hameed, Insights into the modeling of adsorption isotherm systems, 624 Chem. Eng. J. 156 (2010) 2-10.

[40] B.G. Garrett, K. Srinivas, B.K. Ahring, Performance and stability of Amberlite ${ }^{\text {TM }}$ IRA-67 ion exchange resin for product extraction and $\mathrm{pH}$ control during homolactic fermentation of corn stover sugars, Biochem. Eng. J. 94 (2015) 1-8.

[41] T. Qin, M. Song, K. Jiang, J. Zhou, W. Zhuang, Y. Chen, D. Liu, X. Chen, H. Ying, J.

$\mathrm{Wu}$, Efficient decolorization of citric acid fermentation broth using carbon materials prepared from phosphoric acid activation of hydrothermally treated corncob, RSC Advances 7 (2017) $37112-37121$.

[42] M.T. Stone, M. Kozlov, Separating proteins with activated carbon, Langmuir 30 (2014) 8046-8055.

634 [43] M. Boon, K. Van’t Riet, A. Janssen, Enzymatic synthesis of oligosaccharides: product 635 removal during a kinetically controlled reaction, Biotechnol. Bioeng. 70 (2000) 411-420.

636 [44] C.M. Nguyen, G.J. Choi, Y.H. Choi, K.S. Jang, J.-C. Kim, d- and l-lactic acid production 637 from fresh sweet potato through simultaneous saccharification and fermentation, Biochem. 638 Eng. J. 81 (2013) 40-46.

639 [45] K. Wang, W. Li, Y. Fan, W. Xing, Integrated membrane process for the purification of 640 lactic acid from a fermentation broth neutralized with sodium hydroxide, Ind. Eng. Chem. Res. $64152(2013) 2412-2417$. 
642 [46] A.M. Eyal, P. Elankovan, Process for the recovery of lactic acid from aqueous lactate salt

643 solutions, involving the use of ion exchangers, Google Patents, 2007.

644 [47] C.S. Proikakis, P.A. Tarantili, A.G. Andreopoulos, Synthesis and Characterization of Low 645 Molecular Weight Polylactic Acid, J. Elastom. Plast. 34 (2002) 49-63.

646 [48] K.W. Kim, S.I. Woo, Synthesis of High-Molecular-Weight Poly (L-lactic acid) by Direct 647 Polycondensation, Macromol. Chem. Phys. 203 (2002) 2245-2250.

648 [49] D. Marques, S. Jarmelo, C. M. S. G. Baptista, H. Gil, Poly(lactic acid) Synthesis in 649 Solution Polymerization, Macromol. Symp. 296 (2010) 63-71.

650 [50] S. Pivsa-Art, T. Tong-ngok, S. Junngam, R. Wongpajan, W. Pivsa-Art, Synthesis of 651 Poly(D-Lactic Acid) Using a 2-Steps Direct Polycondensation Process, Energy Procedia. 34 652 (2013) 604-609.

653 [51] J. Zhao, R.M. Wilkins, Low Molecular Weight Polylactic Acid as a Matrix for the Delayed 654 Release of Pesticides, J. Agric. Food Chem. 53 (2005) 4076-4082.

655 [52] R. Jalil, J.R. Nixon, Biodegradable poly(lactic acid) and poly(lactide-co-glycolide) 656 microcapsules: problems associated with preparative techniques and release properties, J. 657 Microencapsul. 7 (1990) 297-325.

658 [53] M.S. Lopes, A.L. Jardini, R.M. Filho, Poly (Lactic Acid) Production for Tissue 659 Engineering Applications, Procedia Eng. 42 (2012) 1402-1413.

660 [54] T.M. Quynh, H. Mitomo, M. Yoneyama, N.Q. Hien, Properties of radiation-induced 661 crosslinking stereocomplexes derived from poly(L-lactide) and different poly(D-lactide), 662 Polym. Eng. Sci. 49 (2009) 970-976. 
663 [55] F. Achmad, K. Yamane, S. Quan, T. Kokugan, Synthesis of polylactic acid by direct 664 polycondensation under vacuum without catalysts, solvents and initiators, Chem. Eng. J. 151 665 (2009) 342-350.

666 [56] S.H. Kim, Y.H. Kim, Direct condensation polymerization of lactic acid, Macromol. 667 Symp., Wiley Online Library, 1999, pp. 277-287.

668 [57] Y. Zhao, Z. Wang, J. Wang, H. Mai, B. Yan, F. Yang, Direct synthesis of poly(D,L-lactic 669 acid) by melt polycondensation and its application in drug delivery, J. Appl. Polym. Sci. 91 $670 \quad$ (2004) 2143-2150.

671 [58] W. Huang, N. Cheng, Y. Qi, T. Zhang, W. Jiang, H. Li, Q. Zhang, Synthesis of high 672 molecular weight poly(l-lactic acid) and poly(d-lactic acid) with improved thermal stability via 673 melt/solid polycondensation catalyzed by biogenic creatinine, Polymer 55 (2014) 1491-1496.

674 [59] C. Liu, Y. Jia, A. He, Preparation of Higher Molecular Weight Poly (L-lactic Acid) by 675 Chain Extension, Int. J. Polym. Sci. 2013 (2013) 6.

676 [60] V. Lassalle, M.L. Ferreira, Lipase-catalyzed synthesis of polylactic acid: an overview of 677 the experimental aspects, J. Chem. Technol. Biotechnol. 83 (2008) 1493-1502.

678 [61] C. Chuensangjun, C. Pechyen, Y. Chisti, S. Sirisansaneeyakul, Lipase-catalysed 679 polymerization of lactic acid and the properties of the polymer, Advanced Materials Research, 680 Trans Tech Publ, 2012, pp. 154-157.

681 682 
683

Figure Captions

684 Figure 1: Effect of (a) $\mathrm{pH}$ and (b) temperature on lactic acid binding by four anionic resins

685

686 Figure 2: Adsorption isotherms of lactic acid to (a) Amberlite ${ }^{\circledR}$ IRA67 and (b) Diaion ${ }^{\circledR}$

687 WA30 at $25^{\circ} \mathrm{C} ;$ - - - Langmuir model, ...... Freundlich model, __ Langmuir-Freundlich

688 model

689

690 Figure 3: Elution profiles of lactic acid from the Amberlite ${ }^{\circledR}$ IRA67 resin (saturated with $20 \mathrm{ml}$

691 of $30 \mathrm{~g} / \mathrm{l}$ lactic acid) at different concentrations of $\mathrm{HCl}$ at $25^{\circ} \mathrm{C} ;(-\bullet) 0.05 \mathrm{M},\left({ }^{\star}\right) 0.1 \mathrm{M} \mathrm{HCl}$,

$692(--) 0.5 \mathrm{M} \mathrm{HCl}$ and $(*) 1.0 \mathrm{M} \mathrm{HCl}$.

693

694 Figure 4: Samples of fermentation broth treated with different concentrations of activated 695 carbon at $25{ }^{\circ} \mathrm{C}$ for $1.5 \mathrm{~h}$

696

697 Figure 5: Elution profile of fermentation broth on (a) cation exchange chromatography with 698 Amberlite IRA120 $\left(\mathrm{H}^{+}\right)$resin and (b) adsorption and elution profile of fermentation broth 699 during anion exchange chromatography with Amberlite ${ }^{\circledR} \mathrm{IRA} 67\left(\mathrm{Cl}^{-}\right)$resin 
706 Table 1: Properties of ion exchange resins (information provided by Sigma-Aldrich, US)

\begin{tabular}{|c|c|c|c|c|c|c|}
\hline $\begin{array}{l}\text { Ion exchange } \\
\text { type }\end{array}$ & Resin & Strength & $\begin{array}{l}\text { Particle size } \\
(\mu \mathrm{m})\end{array}$ & Matrix & $\begin{array}{c}\text { Active } \\
\text { functional } \\
\text { group }\end{array}$ & pH \\
\hline Anion & Amberlite ${ }^{\circledR}$ IRA67 & $\begin{array}{c}\text { Weak } \\
\text { basicity }\end{array}$ & $500-750$ & Acrylic (gel) & Tertiary amine & $0-7$ \\
\hline Anion & Diaion $^{\circledR}$ WA30 & $\begin{array}{l}\text { Weak } \\
\text { basicity }\end{array}$ & 680 & $\begin{array}{c}\text { Styrene- } \\
\text { divinylbenzene } \\
\text { (highly porous) }\end{array}$ & Tertiary amine & $0-9$ \\
\hline Anion & Amberlite ${ }^{\circledR}$ IRA400 & $\begin{array}{l}\text { Strong } \\
\text { basicity }\end{array}$ & $600-750$ & $\begin{array}{c}\text { Styrene- } \\
\text { divinylbenzene } \\
\text { (gel) }\end{array}$ & $\begin{array}{l}\text { Quaternary } \\
\text { ammonium }\end{array}$ & $0-14$ \\
\hline Anion & $\begin{array}{c}\text { Dowex }^{\circledR} \text { Marathon } \\
\text { MSA }\end{array}$ & $\begin{array}{l}\text { Strong } \\
\text { basicity }\end{array}$ & 640 & $\begin{array}{c}\text { Styrene- } \\
\text { divinylbenzene } \\
\text { (macroporous) }\end{array}$ & $\begin{array}{l}\text { Quaternary } \\
\text { ammonium }\end{array}$ & $0-14$ \\
\hline Cation & Amberlite ${ }^{\circledR}$ IRA120 & $\begin{array}{l}\text { Strong } \\
\text { acidity }\end{array}$ & $620-830$ & $\begin{array}{c}\text { Styrene- } \\
\text { divinylbenzene } \\
\text { (gel) }\end{array}$ & Sulfonic acid & $0-14$ \\
\hline
\end{tabular}

707

708

709

710

711

712

713

714

715

716

717

718 
719 Table 2: Langmuir, Freundlich and Langmuir - Freundlich isotherm parameters describing 720 the adsorption of lactic acid to Amberlite ${ }^{\circledR}$ IRA67 and Diaion ${ }^{\circledR}$ WA30

\begin{tabular}{lccc}
\hline \multicolumn{1}{c}{ Model } & Parameter & Amberlite $^{\circledR}$ IRA67 & Diaion $^{\circledR}$ WA30 \\
\hline \multirow{2}{*}{ Langmuir } & $q_{\max }(\mathrm{mg} / \mathrm{g})$ & 162.09 & 102.47 \\
& $K$ & 0.0096 & 0.019 \\
& $R^{2}$ & 0.910 & 0.940 \\
& & & \\
Freundlich & $K_{f}$ & 10.88 & 13.379 \\
& $n$ & 2.475 & 3.200 \\
& $R^{2}$ & 0.801 & 0.800 \\
Langmuir-Freundlich & $q_{\max }(\mathrm{mg} / \mathrm{g})$ & 136.11 & 91.51 \\
& $K_{L F}$ & 0.0002 & 0.001 \\
& $n L F$ & 1.96 & 1.83 \\
& $R^{2}$ & 0.940 & 0.965 \\
\hline
\end{tabular}

721

722

723

724

725

726

727

728

729

730

731

732 
733 Table 3: Recovery of D-lactic acid, free amino nitrogen, oligosaccharides and

734 monosaccharides after treatment with activated carbon at different concentrations

\begin{tabular}{|c|c|c|c|c|c|c|}
\hline \multirow{3}{*}{$\begin{array}{l}\text { Activated } \\
\text { carbon } \\
(\%, w / v)\end{array}$} & & \multicolumn{5}{|c|}{ *Recovery (\%) } \\
\hline & \multirow[t]{2}{*}{ D-lactic acid } & \multirow{2}{*}{$\begin{array}{c}\text { Free } \\
\text { amino } \\
\text { nitrogen }\end{array}$} & \multicolumn{2}{|c|}{ Oligosaccharides } & \multicolumn{2}{|c|}{ Monosaccharides } \\
\hline & & & Xylotriose & Xylobiose & Xylose & Arabinose \\
\hline 0 & $100 \pm 0.0$ & $100 \pm 2.5$ & $100 \pm 0.0$ & $100 \pm 0.0$ & $100 \pm 0.0$ & $100 \pm 0.0$ \\
\hline 1 & $95 \pm 0.4$ & $94.0 \pm 0.2$ & $77.4 \pm 0.5$ & $87.6 \pm 0.0$ & $90.4 \pm 0.9$ & $83.4 \pm 1.6$ \\
\hline 5 & $90 \pm 0.3$ & $83.6 \pm 1.3$ & 0 & $42.8 \pm 1.0$ & $85.7 \pm 0.6$ & $79.9 \pm 0.9$ \\
\hline 7 & $88 \pm 3.4$ & $83.0 \pm 1.2$ & 0 & 0 & $82.2 \pm 3.0$ & $76.7 \pm 2.7$ \\
\hline 10 & $85 \pm 1.9$ & $80.2 \pm 2.8$ & 0 & 0 & $72.7 \pm 1.7$ & $70.0 \pm 1.4$ \\
\hline
\end{tabular}

735 *Initial concentration in the fermentation broth: D- lactic acid, $25.9 \mathrm{~g} / \mathrm{l}$; xylotriose, $1.0 \mathrm{~g} / \mathrm{l}$; xylobiose,

$7363.8 \mathrm{~g} / \mathrm{l}$; xylose, $4.8 \mathrm{~g} / \mathrm{l}$; arabinose, $0.5 \mathrm{~g} / \mathrm{l}$ and free amino nitrogen, $152.8 \mathrm{mg} / \mathrm{l}$

737

738

739

740

741

742 
743 Table 4: Recovery and purity of D-lactic acid from the fermentation broth during the different downstream processing stages

\begin{tabular}{|c|c|c|c|c|c|c|c|c|c|c|}
\hline \multirow{2}{*}{ Purification stages } & \multirow{2}{*}{$\begin{array}{l}\text { Volume } \\
(\mathrm{ml})\end{array}$} & \multicolumn{3}{|c|}{ D-lactic Acid } & \multicolumn{2}{|c|}{$\begin{array}{c}\text { Total } \\
\text { Oligosaccharides }\end{array}$} & \multicolumn{2}{|c|}{$\begin{array}{c}\text { Total } \\
\text { Monosaccharides }\end{array}$} & \multicolumn{2}{|c|}{ Free amino nitrogen } \\
\hline & & $\mathrm{g} / \mathrm{l}$ & $\begin{array}{c}\text { Recovery } \\
(\%)\end{array}$ & $\begin{array}{l}\text { Purity* } \\
(\%)\end{array}$ & $\mathrm{g} / \mathrm{l}$ & $\begin{array}{l}\text { Cumulative } \\
\text { removal (\%) }\end{array}$ & $\mathrm{g} / 1$ & $\begin{array}{l}\text { Cumulative } \\
\text { removal (\%) }\end{array}$ & $\mathrm{mg} / \mathrm{l}$ & $\begin{array}{l}\text { Cumulative } \\
\text { removal (\%) }\end{array}$ \\
\hline Fermentation broth & 50 & 25.9 & 100 & 54.6 & 4.5 & 0 & 5.3 & 0 & 152.8 & 0 \\
\hline 7\% Activated carbon & 92 & 13.5 & 95.9 & 64.2 & 0 & 100 & 2.7 & 4.5 & 37.8 & 55 \\
\hline $\begin{array}{l}\text { Cation exchange } \\
\text { chromatography } \\
\left(\text { Amberlite }{ }^{\circledR} \text { IRA120, } \mathrm{H}^{+}\right)\end{array}$ & 132 & 9.1 & 92.5 & 65.2 & 0 & 100 & 1.7 & 26.2 & 0.6 & 99 \\
\hline $\begin{array}{l}\text { Anion exchange } \\
\text { chromatography } \\
\left(\text { Amberlite }{ }^{\circledR} \mathrm{IRA} 67, \mathrm{Cl}^{-}\right)\end{array}$ & 29 & 36.0 & 80.4 & 91.8 & 0 & 100 & 0 & 100 & 0.4 & 99 \\
\hline
\end{tabular}

$744 *$ The purity (\%) of lactic acid in the eluate was determined according to Equation 
Table 5: Comparisons of molecular weight of PLA produced form this and other studies, 746 using different synthesis methods, catalysts and monomers were.

\begin{tabular}{|c|c|c|c|c|c|}
\hline Method & $\begin{array}{c}\text { Lactic } \\
\text { acid } \\
\text { form }\end{array}$ & Catalyst & Polymer & $\begin{array}{c}\text { Molecular } \\
\text { weight }(\mathrm{Da})\end{array}$ & Reference \\
\hline \multirow[t]{3}{*}{$\begin{array}{l}\text { Azeotropic } \\
\text { polycondensation }\end{array}$} & $\mathrm{D}$ & $\begin{array}{l}\text { Tin (1l)-2-ethylhexanoate, } \\
\mathrm{SnC}_{16} \mathrm{H}_{30} \mathrm{O}_{4}\end{array}$ & PDLA & 3010 & $\begin{array}{l}\text { This } \\
\text { study }\end{array}$ \\
\hline & $\mathrm{L}$ & $\begin{array}{l}\text { Tin (ll) chloride dihydrate, } \\
\mathrm{SnCl}_{2} .2 \mathrm{H}_{2} \mathrm{O}\end{array}$ & PLLA & 33000 & [48] \\
\hline & $\mathrm{L}$ & $\begin{array}{l}\text { Tin (ll) chloride dihydrate, } \\
\mathrm{SnCl}_{2} .2 \mathrm{H}_{2} \mathrm{O}\end{array}$ & PLLA & 80000 & [49] \\
\hline Direct & $\mathrm{L}$ & - & PLLA & 90000 & {$[55]$} \\
\hline polycondensation & $\mathrm{L}$ & Antimony trioxide, $\mathrm{Sb}_{2} \mathrm{O}_{3}$ & PLLA & 67000 & [56] \\
\hline $\begin{array}{l}\text { Melt } \\
\text { polymerisation }\end{array}$ & DL & Tin (ll) chloride, $\mathrm{SnCl}_{2}$ & PDLLA & 4100 & {$[57]$} \\
\hline $\begin{array}{l}\text { 1.Solid state } \\
\text { polymerisation } \\
\text { (SSP) } \\
\text { 2.Melt } \\
\text { polymerisation }\end{array}$ & $\mathrm{L}$ & Creatinine, CR & PLLA & 120000 & {$[58]$} \\
\hline $\begin{array}{l}\text { 1. Melt } \\
\text { polymerisation } \\
\text { 2. Solid state } \\
\text { polymerisation } \\
(\mathrm{SSP})\end{array}$ & $\mathrm{D}$ & $\begin{array}{l}\text { 2-Naphthalenesulfonic acid } \\
\text { (2-NSA) }\end{array}$ & PDLA & 33300 & {$[50]$} \\
\hline $\begin{array}{l}\text { 1.Ring opening } \\
\text { polymerisation } \\
\text { (ROP) } \\
\text { 2.Chain extension }\end{array}$ & $\mathrm{L}$ & $\begin{array}{l}\text { 1.Tin (ll)-2-ethylhexanoate, } \\
\mathrm{C}_{16} \mathrm{H}_{30} \mathrm{O}_{4} \mathrm{Sn} \\
\text { 2.Hexamethylene } \\
\text { diisocyanate, HDI }\end{array}$ & PLLA & 203000 & [59] \\
\hline $\begin{array}{l}\text { Enzymatic } \\
\text { polymerisation }\end{array}$ & $\begin{array}{c}\mathrm{DL} \\
\mathrm{L}\end{array}$ & $\begin{array}{l}- \\
-\end{array}$ & $\begin{array}{l}\text { PDLLA } \\
\text { PLLA }\end{array}$ & $\begin{array}{l}2400 \\
4500\end{array}$ & $\begin{array}{l}{[60]} \\
{[61]}\end{array}$ \\
\hline
\end{tabular}


(a)

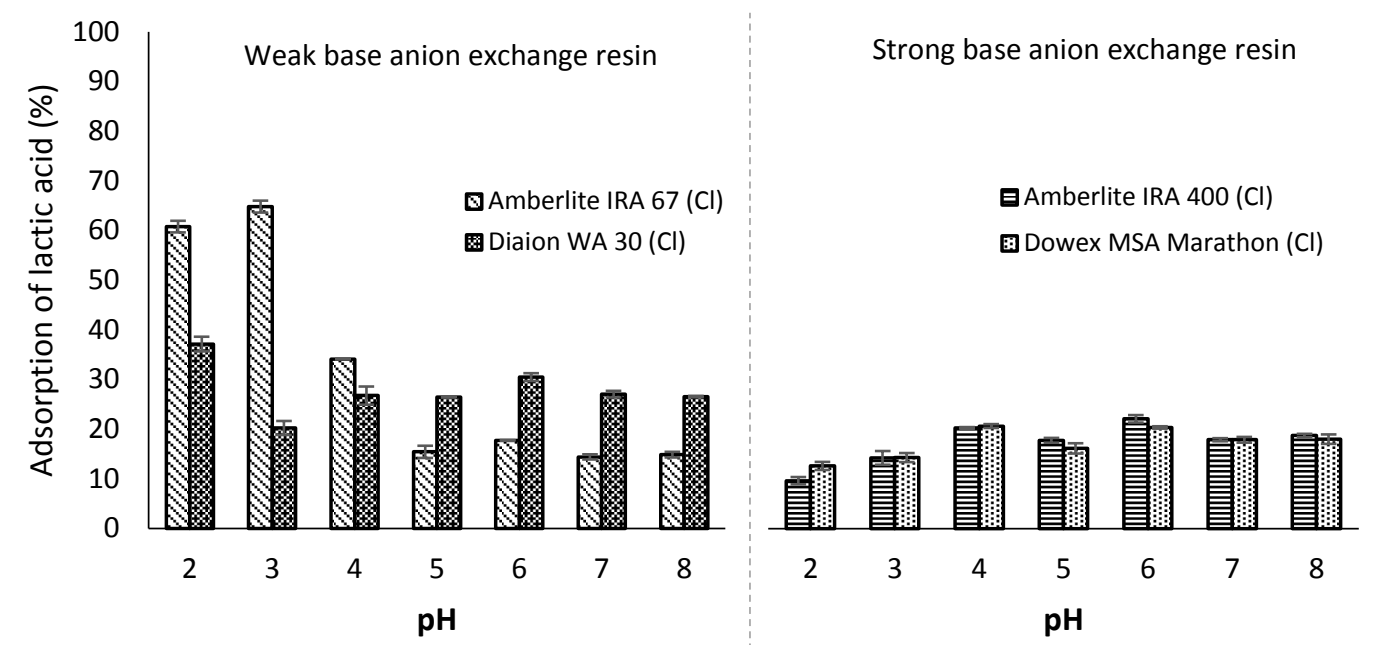

(b)

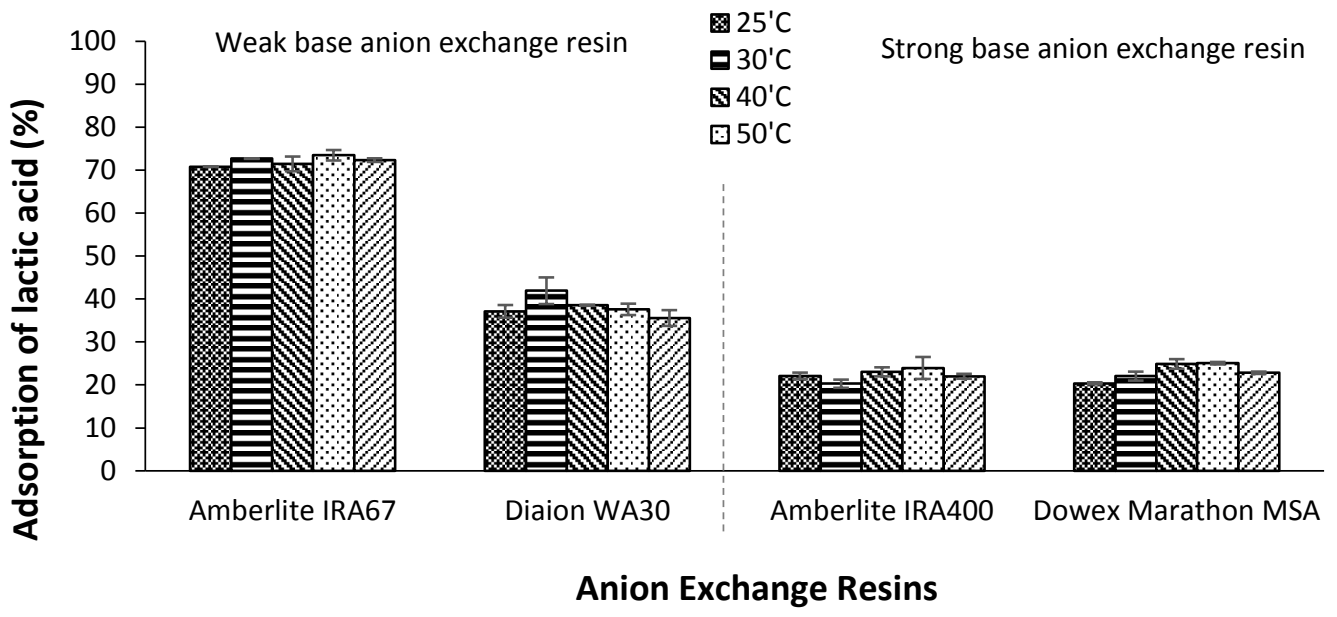


(a)

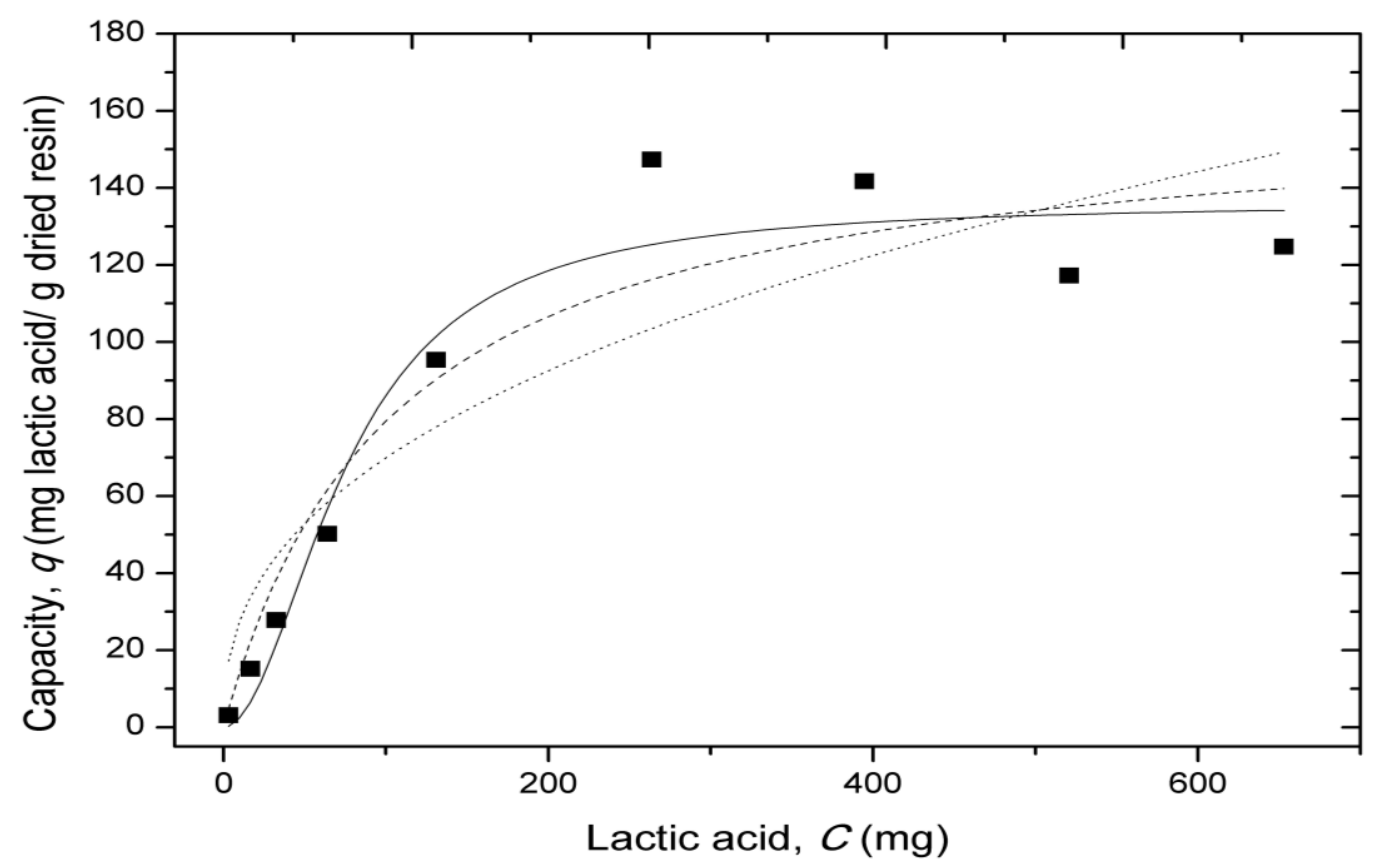

761

762

(b)

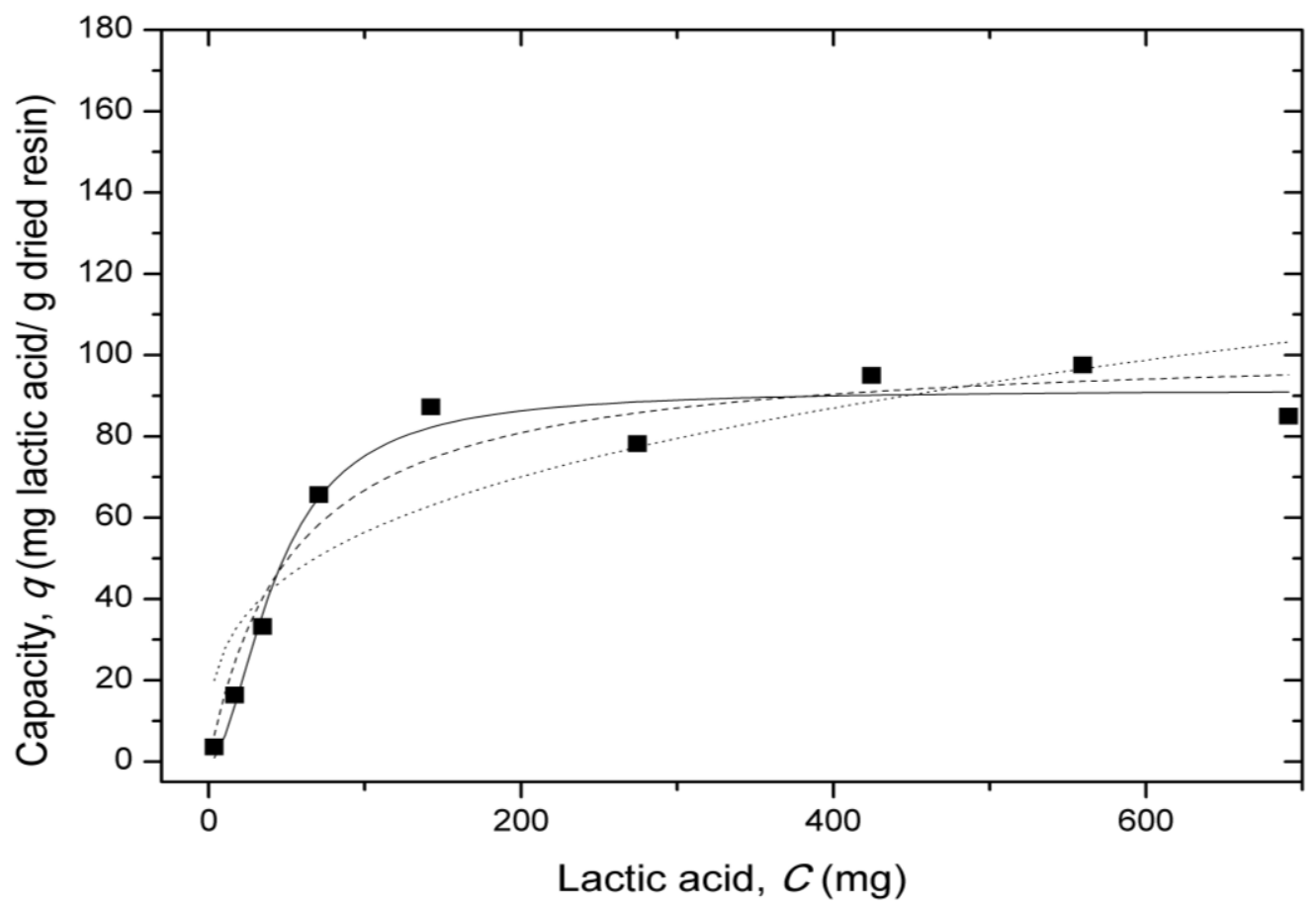

Figure 7 


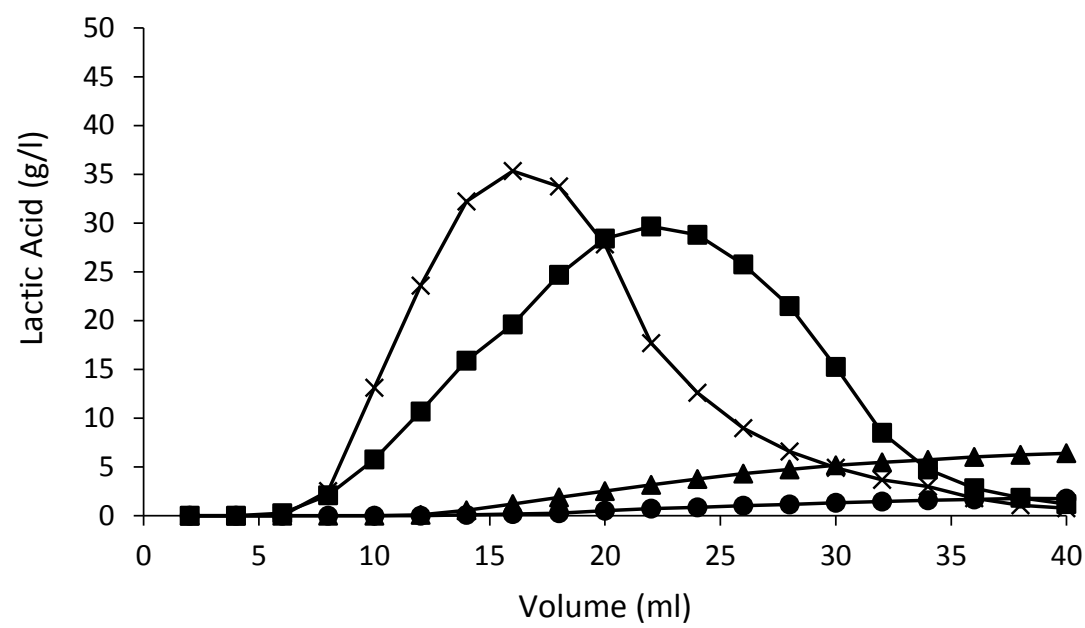

767

768

Figure 8

769

770

771

772

773

774

775

776

777 


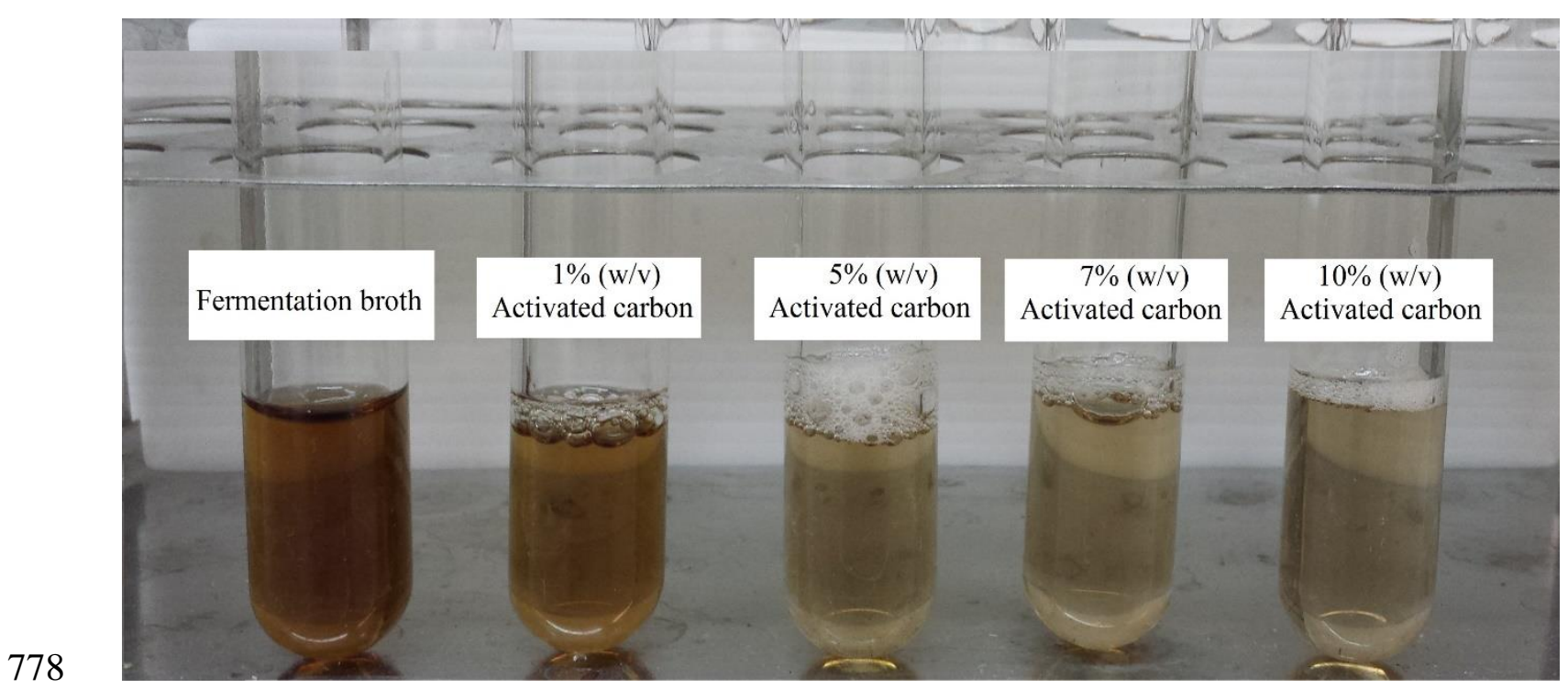

Figure 9

780

781

782

783

784

785

786

787

788

789

790

791

792

793 
Pooled, $\mathrm{pH}<3$

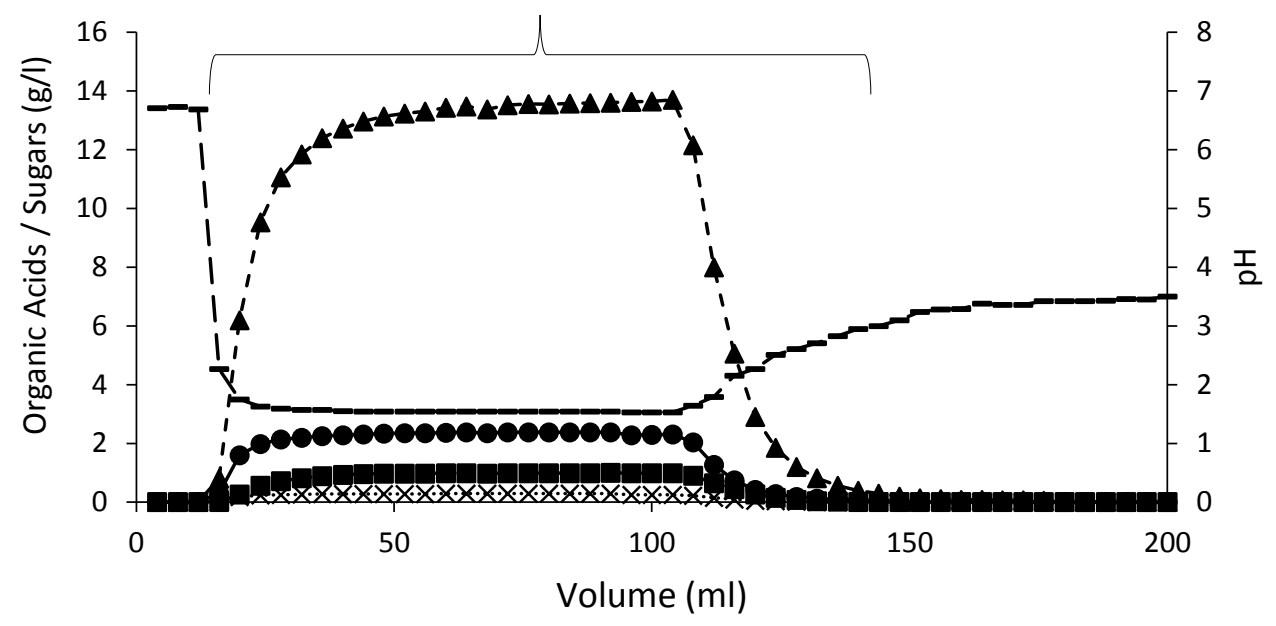

796

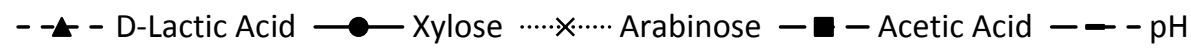

797

798

799

800

801

802

(b)

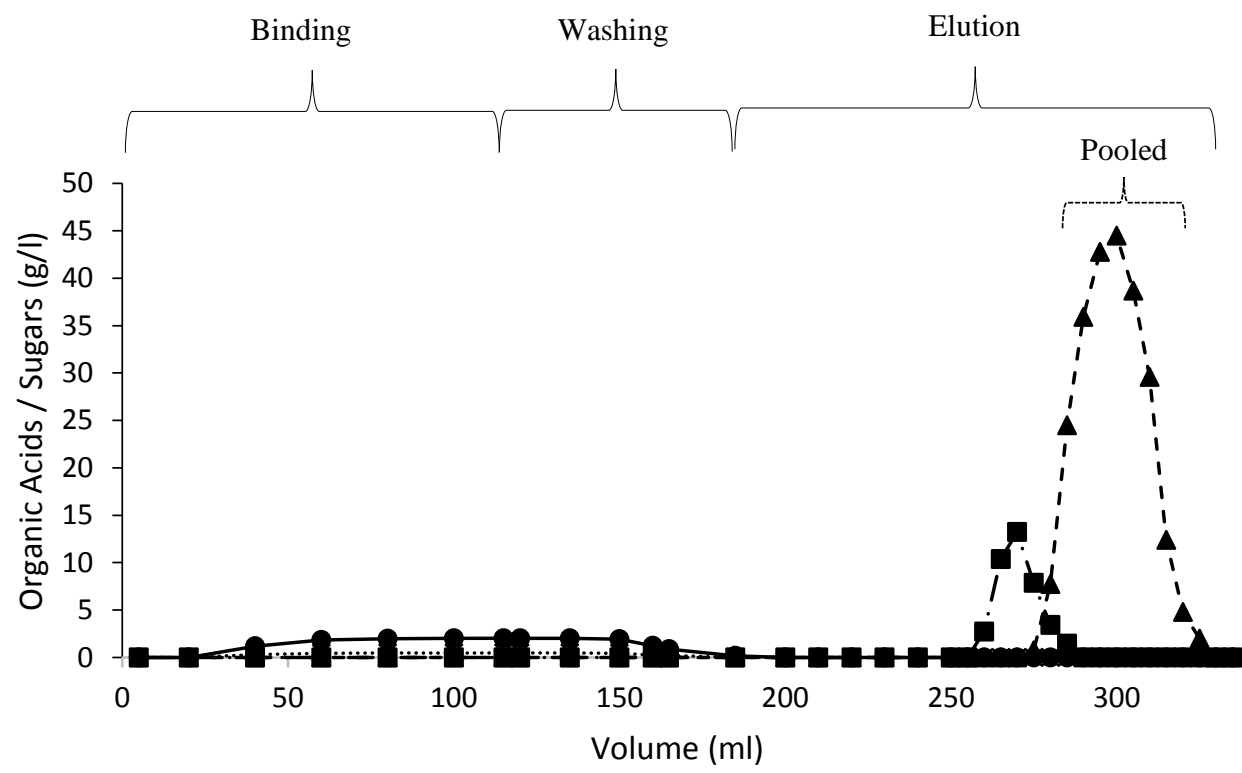

803

$\longrightarrow$ Xylose $\quad$.......... Arabinose - - - - D-LacticAcid - - Acetic Acid 